UDC 547.913:543.544.32

\title{
ESSENTIAL OIL COMPOSITION OF TWO SPECIES OF SCUTELLARIA AERIAL PARTS
}

\author{
(C) A.M. Karimov $v^{I}$, Kh.M. Bobakulov ${ }^{1,2}$, Yu.V. Ostroushko ${ }^{3}$, E.Kh. Botirov ${ }^{3 *}$, A.A. Mamadrahimov ${ }^{4}$, \\ N.D. Abdullaev ${ }^{l}$ \\ ${ }^{1}$ Acad. S. Yu. Yunusov Institute of the Chemistry of Plant Substances, Academy of \\ Sciences of the Republic of Uzbekistan, ul. M. Ulugbeka, 77, Tashkent, 100170 \\ (Uzbekistan) \\ ${ }^{2}$ Tashkent Institute of Irrigation and Agricultural Mechanization Engineers, ul. Kori \\ Niyoziy, 39, Tashkent, 100000 (Uzbekistan) \\ ${ }^{3}$ Surgut State University, ul. Lenina, 1, Surgut, 628412 (Russia), \\ e-mail: botirov-nepi@mail.ru \\ ${ }^{4}$ Institute of Bioorganic Chemistry, UzAS, ul. M. Ulugbeka, 83, Tashkent, 100125 \\ (Uzbekistan)
}

The chemical composition of essential oils obtained by hydrodistillation method from two plants of the genus Scutellaria, grown in Uzbekistan and used in folk medicine were comparatively investigated by GC/MS and FID. Overall individually thirty three constituents were identified in both of aerial parts of $S$. adenostegia and S. comosa essential oils, representing 94.4 and $97.0 \%$ of the total, respectively. The main components were determined as acetophenone $(24.2 \%)$, eugenol (12.3\%), caryophyllene oxide (8.9\%), and $\beta$-caryophyllene (7.0\%) in the oil of S. adenostegia. $\beta$-Caryophyllene (12.5\%), phytol (11.4\%), linalool (11.1\%), acetophenone (10.4\%), caryophyllene oxide (6.6\%),1-hexanol (5.3\%), and $(E)$-2-hexenal $(5.1 \%)$ were found as major components in the $S$. comosa oil. The composition of the oils of $S$. adenostegia and $S$. comosa was being reported for the first time. The essential oils of $S$. adenostegia and S. comosa showed significant antimicrobial properties against Bacillus subtilis, moderate effect against Salmonella enterica and Escherichia coli.

Keywords: Scutellaria adenostegia; Scutellaria comosa; essential oil; GC/MS/FID; antibacterial activity.

This work was supported by the Program for Fundamental Scientific Research of the Uzbekistan Academy of Sciences under the Grant VA-FA-F6-010.

\section{Introduction}

The genus of Scutellaria L., skullcaps, "Ko'kamaron" (local name) which belongs to the family Lamiaceae, is represented by 360 species and is widely spread in mild, subtropical, and tropical regions of the world, including Eu-

Karimov Abdurashid Musakhonovich - PhD (Chemistry), Senior Researcher, Laboratory of Chemistry of coumarins and terpenoids, e-mail: abdurashidka@mail.ru Bobakulov Khairulla Mamadievich - Candidate of Chemical Sciences, Senior Researcher, Laboratory of Physical Research Methods, e-mail: khayrulla@rambler.ru Ostroushko Yulia Vladimirovna - postgraduate student, e-mail: julliyaost@gmail.com

Botirov Erkin Khozhiakbarovich - Professor of the Department of Chemistry, e-mail: botirov-nepi@mail.ru Mamadrakhimov Azimjon Akparalievich - Candidate of Chemical Sciences, Senior Researcher, Laboratory of Complex Compounds, e-mail: kimyogar@yahoo.com Abdullaev Nasrulla Jalilovich - Professor, leading researcher, Laboratory of Physical Methods of Research, e-mail: n_abdullaev@rambler.ru rope, North America, and Eastern Asia [1]. Approximately 120 species and subspecies of the genus grow across the countries of Commonwealth of Independent States (CIS), mainly in the Caucasus Mountains and in Middle Asia [1, 2]. Skullcaps are perennial or, very rarely, annual grasses, rarely subshrubs or half-shrubs. Many of the skullcap species are decorative plants, some are medicinal herbs, but all belong to dyeing plants. In Uzbekistan, there are thirty eight species of the Scutellaria L. genus plants. It is used in Uzbekistan in treatment of inflammation, chorea, nervous tension and high-blood pressure [3]. Chemical composition of

\footnotetext{
${ }^{*}$ Corresponding author.
} 
plants of the Scutellaria L. genus is diverse. Earlier, flavonoids, phenylpropanoids, phenolic acids, iridoids, clerodane diterpenoids, steroids, triterpenes, lignans, alkaloids, phytosterols, polysaccharides, tannin substances, essential oils, and other classes of natural compounds have been isolated from different species [1, 2, 4]. S. adenostegia Briq. is a perennial native plant growing on rocky and clay mountain slopes, dried up riverbeds and streams, rocky placers and gravels along the banks of the rivers of Tian-Shan, Pamir-Alay Mountains (Central Asia). Previous phytochemical studies on this plant reported the isolation and identification of flavonoids [3]. S. comosa Juz. mainly occurring in the Tian Shan and Pamir-Alai Mountains, it is a perennial shrub species which endemic to the Central Asia. Flavonoids on this plant species have been extensively studied [3,5]. Several authors reported on the study of essential oils of plants of Scutellaria genus [1, 6-10].

It was previously reported that essential oils isolated from plants of this genus possess antioxidant and antibacterial activities [10-14]. In the literature, there is a report on the study of the component composition and antioxidant activity of essential oils of three species of plants of the genus Scutellaria, growing in Uzbekistan [10]. But until now, there are no published reports concerning the phytochemistry and biological activities of the essential oils of $S$. adenostegia and S. comosa. We have reported here the isolation and characterization of essential oils, which to the best of our knowledge, is the first investigation on volatile compositions of the aerial parts of two Scutellaria species.

\section{Experimental}

The aerial parts (stems, leaves, flowers) of S. adenostegia and S. comosa employed in this investigation were collected in the flowering stage (May, 2019) from Chust $\left(41^{\circ} 00^{\prime} 00^{\prime \prime} \mathrm{N} 71^{\circ} 13^{\prime} 59.88^{\prime \prime} \mathrm{E}\right)$ and Turakurgan District $\left(41^{\circ} 00^{\prime} 00^{\prime \prime} \mathrm{N} 71^{\circ} 30^{\prime} 56.88^{\prime \prime}\right.$ E) Namangan Region of Uzbekistan respectively. The plants were identified at the Flora of Uzbekistan Department, Institute of Botany (Uzbekistan) by Dr. O.T. Turginov. The voucher specimens of $S$. adenostegia (accession number (A.N.) N20190550) and S. comosa (A.N. N20190551) have been deposited at the Flora of Uzbekistan Department. Isolation of the essential oil. The air-dried aerial parts (moisture content was 11$13 \%$ w.b.) of the S. adenostegia and S. comosa were hydrodistilled three times $(3 \times 100 \mathrm{~g}$ each) for $3 \mathrm{~h}$, using a Clevenger-type apparatus. Further hydrodistillation of plant raw materials did not lead to an increase in the yield of essential oil. The obtained essential oils were then dried using anhydrous sodium sulfate and stored at $4{ }^{\circ} \mathrm{C}$ in the dark until use. The essential oil content was calculated as a relative percentage $(\mathrm{v} / \mathrm{w})$ of the dry plant material.

$G C$ and GC/MS analysis of essential oils. The qualitative and quantitative composition of the essential oils were determined on an Agilent 5977B MSD/8890A GC (Agilent Technologies, USA) gas chromatography-mass spectrometer equipped with flame ionization detector (FID) and an Agilent 7693A ALS autoinjector. The components of the mixture were separated on an Agilent DB-Wax quartz capillary column $(30 \mathrm{~m} \times 250 \mu \mathrm{m} \times 0.25 \mu \mathrm{m}$ film thickness) in the following temperature mode: $50{ }^{\circ} \mathrm{C}(1 \mathrm{~min})-4{ }^{\circ} \mathrm{C} / \mathrm{min}$ to $200{ }^{\circ} \mathrm{C}(6 \mathrm{~min})-15{ }^{\circ} \mathrm{C} / \mathrm{min}$ to $250{ }^{\circ} \mathrm{C}$ (35 $\mathrm{min}$ ). The samples were prepared in dichloromethane and $1.0 \mu \mathrm{L}$ injected in splitting mode $(50: 1)$. The flow rate of the mobile phase $\left(\mathrm{H}_{2}\right)$ was $1.1 \mathrm{~mL} / \mathrm{min}$. The injector temperature was $220^{\circ} \mathrm{C}$. MS conditions were as follows: ionization energy $70 \mathrm{eV}$, source temperature $230^{\circ} \mathrm{C}$, quadrupole temperature $150^{\circ} \mathrm{C}$. EI-MS spectra were obtained in the $m / z$ range of $10-550$ a.m.u.

FID was used for the quantification of the volatile compounds. The chromatographic conditions and the column were identical to those used for the GC/MS analysis. The injector temperature was $250^{\circ} \mathrm{C}$ and the carrier gas was $\mathrm{H}_{2}$ at $1.1 \mathrm{~mL} / \mathrm{min}$.

Components of essential oils were identified by comparison of the chromatographic peaks retention times with those of authentic compounds analyzed under the same conditions, and by comparison of retention indices (as Kovats indices) with literature data [15].

Comparisons of MS fragmentation patterns with mass spectrum database search were performed using the Wiley Registry of Mass Spectral Data-9 ${ }^{\text {th }}$ Ed., NIST Mass Spectral Library (2011) and the Automated Mass Spectral Deconvolution and Identification System (AMDIS, Version 2.72) containing NIST14 Library. A $\mathrm{C}_{9}-\mathrm{C}_{32} n$-alkane standard solution (Agilent Technoligies, USA) was used for the determination of chromatographic retention indices (RI). Percent composition was obtained for each constituent on the basis of flame ionization detection analyses of the essential oils.

Antimicrobial activity. The essential oils antimicrobial activities were assessed against four pathogenic bacterial strains, two Gram-positive Staphylococcus aureus (MTCC 737) and Bacillus subtilis (NK-1, isolated from 
Natto) and two Gram-negative Salmonella enterica (ATCC 14028) and Escherichia coli (MTCC 1302). The above microorganisms were obtained from the Department of Microbiology of the Medical Institute of Surgut State University. The assay was performed using a 96-well microliter plate-based method with resazurin as a cell growth indicator following a previously used method with minor adjustments [16].

Statistical analysis. Results were expressed as mean \pm standard deviation. Statistical comparisons were performed with Student's $t$-test using GraphPad Prism version 7.00. Differences were considered significant at $\mathrm{p}<0.05$.

\section{Results and discussion}

Chemical composition of essential oils. The average yields of essential oils obtained from three independent determinations by the hydrodistillation method were $0.19 \%$ (v/w; S. adenostegia; light yellow), and $0.17 \%$ (v/w; S. comosa; yellow) on a dry weight. The chemical compositions of the essential oils isolated from the air-dried aerial parts of plants were investigated by GC/MS/FID. Chromatographic profile of the volatiles from two Scutellaria species on the DB-Wax column is presented on Figure and Table 1 show the composition of compounds identified from the studied oil samples. Totally thirty three compounds representing $94.4 \%$ of the total oil were characterized in essential oil of S. adenostegia. The classes of compounds present in S. adenostegia were aldehydes and ketones (35.2\%), phenols (16.0\%), alcohols (12.4\%), sesquiterpene hydrocarbons (12.3\%) and oxygenated sesquiterpenes $(11.0 \%)$.

The main compounds of $S$. adenostegia were acetophenone (24.2\%), eugenol (12.3\%), caryophyllene oxide (8.9\%), and $\beta$-caryophyllene (7.0\%). Moreover, high amount of 1 -hexanol (3.8\%), furfural $(3.3 \%)$ and $\gamma$ himachalene $(2.7 \%)$ were also observed in essential oil. It should be noted that acetophenone was also the main component of the essential oils of $S$. immaculate and S. schachristanica [10]. The total phenolic compounds content in essential oil of this plant was $13.3 \%$, of which $11.8 \%$ was eugenol. S. adenostegia essential oil were rather poor in content of oxygenated monoterpenes (3.0\%).

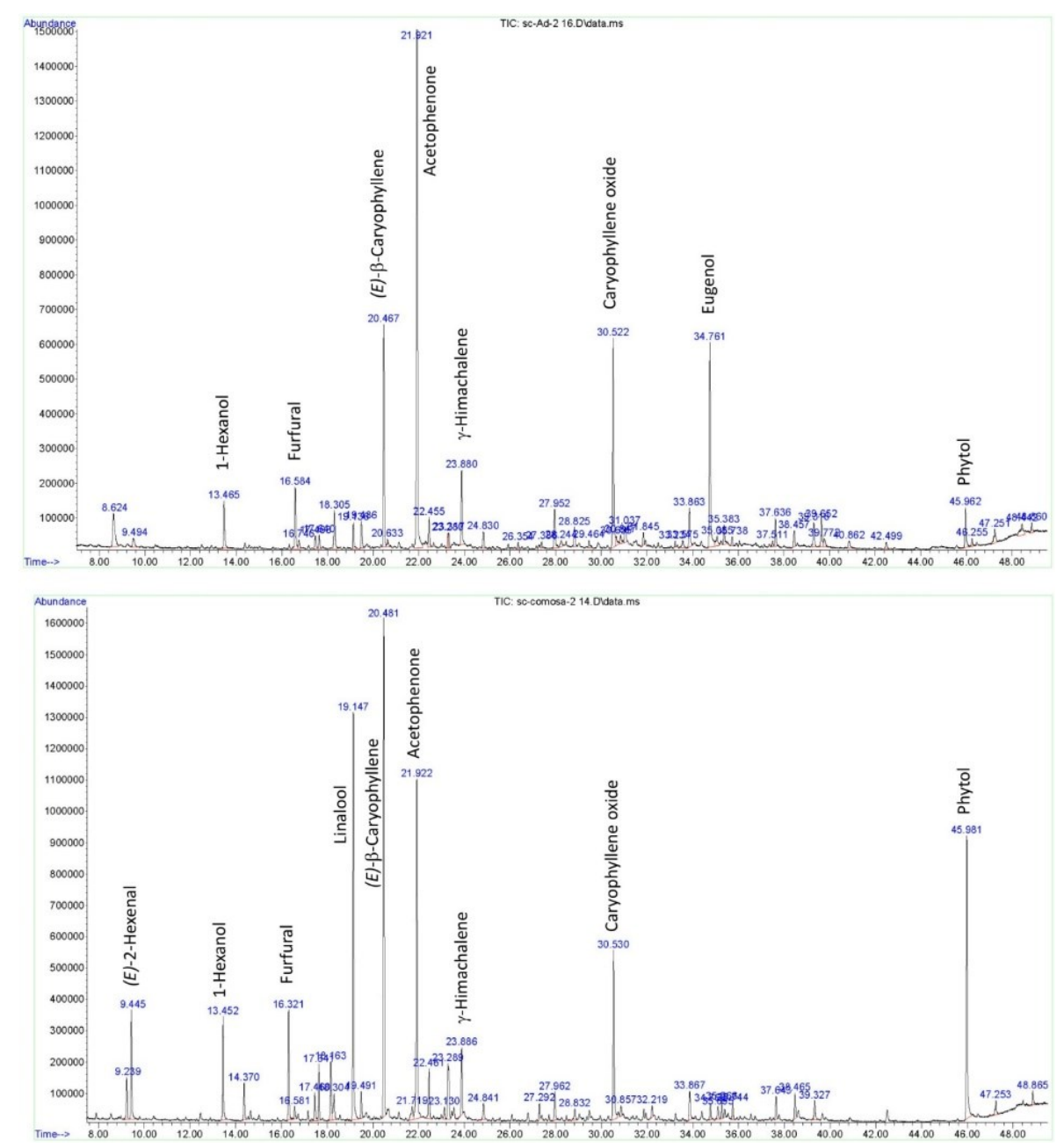


Chromatographic profile of the volatiles from essential oils of Scutellaria adenostegia Briq. (upper) and Scutellaria comosa Juz. (lower)

Table 1. Essential oil composition of two Scutellaria species

\begin{tabular}{|c|c|c|c|c|c|}
\hline No & Compounds & $\mathrm{RT}$, min & LRI* $^{*}$ & $\begin{array}{l}\text { S. adenostegia, } \\
\text { (Conc., \%) }\end{array}$ & $\begin{array}{l}\text { S. comosa, } \\
\text { (Conc., \%) }\end{array}$ \\
\hline 1 & 1,8-Cineol & 9.231 & 1192 & - & 0.9 \\
\hline 2 & (E)-2-Hexenal & 9.495 & 1202 & 1.6 & 5.1 \\
\hline 3 & 1-Hexanol & 13.466 & 1341 & 3.8 & 5.3 \\
\hline 4 & (Z)-3-Hexen-1-ol, & 14.364 & 1369 & - & 2.0 \\
\hline 5 & 1-Octen-3-ol & 16.315 & 1433 & - & 3.9 \\
\hline 6 & Furfural & 16.584 & 1442 & 3.3 & - \\
\hline 7 & $\alpha$-Cubebene & 17.465 & 1472 & 0.7 & 0.8 \\
\hline 8 & Pentadecane & 17.637 & 1500 & - & 1.4 \\
\hline 9 & Camphor & 18.158 & 1516 & - & 1.7 \\
\hline 10 & Benzaldehyde & 18.301 & 1520 & 1.8 & 1.1 \\
\hline 11 & Linalool & 19.142 & 1549 & 1.1 & 11.1 \\
\hline 12 & 1-Octanol & 19.491 & 1560 & 1.9 & 1.5 \\
\hline 13 & $(E)$ - $\beta$-Caryophyllene & 20.475 & 1593 & 7.0 & 12.5 \\
\hline 14 & Acetophenone & 21.923 & 1624 & 24.2 & 10.4 \\
\hline 15 & $\alpha$-Caryophyllene & 22.461 & 1644 & 1.1 & 1.7 \\
\hline 16 & $\alpha$-Terpineol & 23.319 & 1676 & 0.6 & 1.2 \\
\hline 17 & $\gamma$-Himachalene & 23.886 & 1697 & 2.7 & 2.4 \\
\hline 18 & $\delta$-Cadinene & 24.841 & 1733 & 0.8 & 0.5 \\
\hline 19 & Grandlure II & 27.290 & 1829 & - & 0.7 \\
\hline 20 & (Z)-Geranylacetone & 27.387 & 1833 & 0.5 & - \\
\hline 21 & Benzyl alcohol & 27.960 & 1856 & 2.1 & 1.3 \\
\hline 22 & 2-Phenylethanol & 28.835 & 1892 & 1.2 & 0.7 \\
\hline 23 & $(E)-\beta$-Ionone & 29.476 & 1918 & 0.4 & 0.5 \\
\hline 24 & Caryophyllene oxide & 30.546 & 1961 & 8.9 & 6.6 \\
\hline 25 & Alloaromadendrene oxide-(1) & 30.866 & 1974 & - & 0.5 \\
\hline 26 & $o$-Cresol & 31.038 & 1981 & 1.6 & - \\
\hline 27 & $(Z)$-Nerolidol & 31.845 & 2015 & 0.6 & - \\
\hline 28 & 4-Phenyl-3-buten-2-one & 33.573 & 2092 & 0.4 & - \\
\hline 29 & Hexahydrofarnesyl acetone & 33.882 & 2120 & 3.0 & 2.1 \\
\hline 30 & Eugenol & 34.769 & 2145 & 12.3 & 1.3 \\
\hline 31 & $\alpha$-Muurolol & 35.101 & 2159 & 0.6 & 0.9 \\
\hline 32 & $9 \beta$-Acetoxy-3,4,8-trimethyltricyclo[6.3.1.0(1,5)]dodec-3-ene & 35.272 & 2167 & - & 0.8 \\
\hline 33 & $p$-Vinyl-guaiacol & 35.393 & 2172 & 1.3 & 0.6 \\
\hline 34 & Caryophylla-4(12),8(13)-dien-5 $\alpha$-ol & 37.647 & 2272 & 1.5 & 1.2 \\
\hline 35 & Dihydroactinidiolide & 38.471 & 2309 & 1.3 & 1.8 \\
\hline 36 & 8-Cedren-13-ol & 39.335 & 2347 & - & 0.9 \\
\hline 37 & 2,3-Dihydro-benzofuran & 39.650 & 2361 & 2.1 & - \\
\hline 38 & Coumarin & 40.863 & 2416 & 0.7 & - \\
\hline 39 & Pentacosane & 42.528 & 2500 & 0.8 & 1.1 \\
\hline 40 & Phytol & 45.601 & 2643 & 2.8 & 11.4 \\
\hline 41 & Acetovanillone & 46.253 & 2675 & 0.8 & - \\
\hline 42 & Methoxyacetic acid 2-pentadecyl ester & 47.260 & 2723 & 0.9 & 1.1 \\
\hline \multicolumn{4}{|c|}{ Oxygenated monoterpenes $-1,9,11,16,19,35$. } & 3.0 & 17.4 \\
\hline \multicolumn{4}{|c|}{ Sesquiterpene hydrocarbons $-7,13,15,17,18$} & 12.3 & 17.9 \\
\hline \multicolumn{4}{|c|}{ Oxygenated sesquiterpenes $-24,25,31,32,34,36$. } & 11.0 & 10.9 \\
\hline \multicolumn{4}{|c|}{ Aldehydes and ketones - 2, 6, 10, 14, 20, 23, 28, 29.} & 35.2 & 19.2 \\
\hline \multicolumn{4}{|c|}{ Alcohols - 3, 4, 5, 12, 21, 22, 27, 40} & 12.4 & 26.1 \\
\hline \multicolumn{4}{|c|}{ Phenols $-26,30,33,41$} & 16.0 & 1.9 \\
\hline \multicolumn{4}{|c|}{ Others $-8,37,38,39,42$} & 4.5 & 3.6 \\
\hline \multicolumn{4}{|c|}{ Total } & 94.4 & 97.0 \\
\hline \multicolumn{4}{|c|}{ Identified compounds } & 33 & 33 \\
\hline
\end{tabular}

*LRI - Linear retention indices on DB-Wax column; Conc., \% calculated from FID data.

In the essential oil of $S$. comosa thirty five components, representing $97.0 \%$ of the total ones were characterized (Tab. 1). In the studied essential oil alcohols (26.1\%) dominated. Aldehydes and ketones (19.2\%), sesquiterpene 
hydrocarbons $(17.9 \%)$, oxygenated monoterpenes $(17.4 \%)$ and oxygenated sesquiterpenes $(10.9 \%)$ were the remaining groups of components (Tab. 1).

$\beta$-Caryophyllene (12.5\%), phytol (11.4\%), linalool (11.1\%), acetophenone (10.4\%), caryophyllene oxide $(6.6 \%)$, 1-hexanol (5.3\%), and $(E)$-2-hexenal (5.1\%) were found as the main constituents. Literature information indicated that $\beta$-caryophyllene was the main component of the essential oils of S. brevibracteata [6], S. sibthorpii [7], S. luteo-caerulea [9], S. albida [12] and other species. Acetophenone was the main component of $S$. schachristanica and $S$. immaculata essential oil [10], while linalool was determined as a major component for $S$. cypria var. elatior [7]. In total, forty four volatile compounds were identified in two Scutellaria species from Uzbekistan. Aldehydes and ketones, alcohols, phenols and sesquiterpene hydrocarbons are the dominant components of the essential oil of the plant $S$. adenostegia. Sesquiterpene hydrocarbons and oxygenated monoterpenes were the major group of terpenes found in the essential oil of $S$. comosa. On the contrary, monoterpene hydrocarbons were not detected in both oil of $S$. adenostegia and $S$. comosa.

Evaluation of antibacterial activity. The literature contains data on the antimicrobial activity of essential oils of some plants of the Scutellaria genus [7, 11-14]. That is, we have studied the antibacterial properties of the isolated essential oils. The essential oils of $S$. adenostegia and $S$. comosa showed significant antimicrobial properties against Bacillus subtilis $(318.0 \pm 8.62$ and $401.1 \pm 14.49 \mu \mathrm{g} / \mathrm{mL})$, moderate effect against Salmonella enterica $(519.4 \pm 16.29$ and $803.1 \pm 31.62 \mu \mathrm{g} / \mathrm{mL})$ and Escherichia coli $(528.3 \pm 14.63$ and $802.4 \pm 32.57 \mu \mathrm{g} / \mathrm{mL})$, and weak effect against Staphylococcus aureus (1297.6 \pm 34.78 and $1676.3 \pm 52.94 \mu \mathrm{g} / \mathrm{mL})$ respectively (Table 2$)$. We are inclined to believe that the antibacterial activity of essential oils is due to the presence of $\beta$-caryophyllene and eugenol in their composition $[17,18]$. Pure $\beta$-caryophyllene showed more pronounced antibacterial activity against Gram-positive bacteria than Gram-negative bacteria [17]. Overall, the antibacterial activity of the essential oils can be related to the content of many of the compounds identified in the oils, including eugenol and $\beta$-caryophyllene.

Table 2. Minimum inhibition concentration (MIC) of essential oils of S. adenostegia and S. comosa against four bacterial strains

\begin{tabular}{l|c|c|c|c}
\hline \multirow{2}{*}{\multicolumn{1}{c|}{ Samples }} & \multicolumn{4}{|c}{ MIC $(\mu \mathrm{g} / \mathrm{mL})^{\mathrm{a}}$} \\
\cline { 2 - 5 } & E. coli & S. aureus & B. substilis & S. enterica \\
\hline Streptomycin $^{\mathrm{b}}$ & $25.8 \pm 1.23$ & $3.1 \pm 0.12$ & $25.8 \pm 1.07$ & $25.8 \pm 1.28$ \\
S. adenostegia. & $528.3 \pm 14.63$ & $1297.6 \pm 34.78$ & $318.0 \pm 8.62$ & $519.4 \pm 16.29$ \\
S.comosa. & $802.4 \pm 32.57$ & $1676.3 \pm 52.94$ & $401.1 \pm 14.49$ & $803.1 \pm 31.62$ \\
\hline
\end{tabular}

${ }^{a}$ All results are presented as mean \pm standard deviations for triplicate assays.

${ }^{\mathrm{b}}$ Reference.

\section{Conclusions}

For the first time, the chemical composition of the essential oils grown in Uzbekistan of two Scutellaria species was studied. Acetophenone and $\beta$-caryophyllene are the dominant terpenes of the essential oils of $S$. adenostegia and $S$. comosa. On the other hand the high amount of eugenol and caryophyllene oxide in essential oil of $S$. adenostegia and linalool, phytol and caryophyllene oxide in essential oil of $S$. comosa were revealed. The essential oils of these plants showed significant antibacterial properties against Bacillus subtilis, moderate effect against Salmonella enterica and Escherichia coli.

\section{References}

1. Shang X., He X., He X., Li M., Zhang R., Fan P., Zhang Q., Jia Z. J. Ethnopharmacol., 2010, vol. 128, pp. $279-313$. DOI: 10.1016/j.jep.2010.01.006.

2. Karimov A.M., Botirov E.Kh. Russian J. Bioorg. Chem., 2017, vol. 43, pp. 691-711. DOI: $10.1134 / \mathrm{S} 1068162017070068$.

3. Khodjimatov K.Kh., Aprasidi G.S., Khodjimatov A.K. Dikorastushie celebniye rasteniya srednei azii. [Wilde type medicinal plants of Central Asia]. Tashkent, 1995, pp. 83-98. (in Russ.).

4. Tashmatov Z.O., Eshbakova K.A., Bobakulov Kh.M. Chem. Nat. Compd., 2011, vol. 47, pp. 440-441. DOI: 10.1007/s10600-011-9955-8.

5. Karimov A.M., Ostroushko Yu.V., Botirov E.Kh. Chem. Nat. Compd., 2019, vol. 55, pp. 545-546. DOI: 10.1007/s10600-019-02737-0.

6. Cicek M., Demirci B., Yilmaz G., Baser K.H.C. Nat. Prod. Res., 2011, vol. 25, pp. 1720-1726. DOI: 10.1080/14786419.2010.512997. 
7. Dereboylu A.E., Sarikahya N.B., Sengonca N., Kirmizigul S., Yasa I., Gucel S., Guvensen A. Asian. J. Chem., 2012, vol. 24, pp. 4911-4916.

8. Miyazawa M., Nomura M., Marumoto S., Mori K. J. Oleo Sci., 2013, vol. 62, pp. 51-56. DOI: 10.5650/jos.62.51.

9. Nikbin M., Kazemipour N., Maghsoodlou M.T., Valizadeh J., Sepehrimanesh M., Davarimanesh A. Avicenna. J. Phytomed., 2014, vol. 4, pp. 182-190. DOI: 10.22038/AJP.2014.1863.

10. Mamadalieva N.Z., Sharopov F.S., Satyal P., Azimova S.S., Wink M. Nat. Prod. Res., 2017, vol. 31, pp. $1172-1176$. DOI: $10.1080 / 14786419.2016 .1222383$.

11. Yu J., Lei J., Yu H., Cai X., Zou G. Phytochemistry, 2004, vol. 65, pp. 881-884. DOI: 10.1016/j.phytochem.2004.02.005.

12. Skaltsa H.D., Lazari D.M., Mavromati A.S., Tiligada E.A., Constantinidis T.A. Planta Med., 2000, vol. 66, pp. 672674. DOI: $10.1055 / \mathrm{s}-2000-8650$.

13. Skaltsa H.D., Lazari D.M., Kyriazopoulos P., Golegou S., Triantaphyllidis S., Sokovic M., Kypriotakis Z. J. Essent. Oil Res., 2005, vol. 17, pp. 232-235. DOI: 10.1080/10412905.2005.9698886.

14. Arıtuluk Z.C., Özkul Koçak C., Renda G., Ekizoğlu M., Ezer N. J. Res. Pharm., 2019, vol. 23, no. 3, pp. $552-558$. DOI: $10.12991 /$ jrp.2019.162.

15. Babushok V.I., Linstrom P.J., Zenkevich I.G. J. Phys. Chem. Ref. Data, 2011, vol. 40, no. 4, pp. 0431011-0431047. DOI: $10.1063 / 1.3653552$.

16. Sarker S.D., Nahar L., Kumarasamy Y. Methods, 2007, vol. 42, pp. 321-324. DOI: 10.1016/j.ymeth.2007.01.006.

17. Dahham S.S., Tabana Y.M., Iqbal M.A., Ahamed M.B.K., Ezzat M.O., Majid A.S.A., Majid A.M.S.A. Molecules, 2015, vol. 20, pp. 11808-11829. DOI: 10.3390/molecules200711808.

18. Marchese A., Barbieri R., Coppo E., Orhan I.E., Daglia M., Nabavi S.F., Izadi M., Abdollahi M., Nabavi S.M., Ajami M. Crit. Rev. Microbiol., 2017, vol. 43, pp. 668-689. DOI: 10.1080/1040841X.2017.1295225.

Received January 4, 2021

Revised April 25, 2021

Accepted June 28, 2021

For citing: Karimov A.M., Bobakulov Kh.M., Ostroushko Yu.V., Botirov E.Kh., Mamadrahimov A.A., Abdullaev N.D. Khimiya Rastitel'nogo Syr'ya, 2021, no. 4, pp. 139-144. (in Russ.). DOI: 10.14258/jcprm.2021049121. 